\title{
KAJIAN AWAL PENGAWETAN IKAN PINDANG BANDENG DAN MOJANG DENGAN PENGEMASAN VAKUM DI DESA CUKANGGENTENG
}

\author{
Hans Kristianto ${ }^{1}$, Ariestya Arlene Arbita ${ }^{1}$, Jenny N M Soetedjo ${ }^{1 *}$, Budi H Bisowarno ${ }^{1}$, \\ Katherine $^{2,1}$, Sharon Pricillia ${ }^{1}$, Hanna Priescilia ${ }^{1}$ \\ ${ }^{1}$ Program Studi Teknik Kimia, Fakultas Teknologi Industri, Universitas Katolik Parahyangan, Jl. \\ Ciumbuleuit no 94 Bandung 40141 \\ ${ }^{2}$ Department of Biotechnology, Indonesia International Institute for Life Sciences (i3L), Jl. Pulomas \\ Barat Kav 88, Jakarta Timur 13210 \\ *Penulis Korespodensi: jenny.novianti@unpar.ac.id
}

\begin{abstract}
Abstrak
Warga Desa Cukanggenteng, Ciwidey, Kabupaten Bandung memproduksi panganan khas berupa ikan pindang sebagai penghasilan tambahan. Berbagai jenis pindang yang dihasilkan di antaranya pindang mojang, pindang bandeng dan pindang ikan mas. Produk pindang ikan yang dihasilkan dijajakan secara berkeliling dan laku terjual. Masalah yang dihadapi adalah produk pindang ikan relatif tidak tahan lama, sehingga pemasarannya terbatas. Pemindangan ikan sendiri sebetulnya sudah merupakan suatu upaya pengawetan. Akan tetapi tanpa pengemasan yang baik, produk pindang ikan akan cenderung mudah rusak dan tidak tahan lama. Kegiatan pengabdian ini berupa kegiatan tahun pertama yang melakukan kajian awal terhadap masalah pengawetan ikan pindang Desa Cukanggenteng. Kegiatan yang dilakukan terdiri atas studi awal kondisi produksi ikan pindang, uji coba laboratorium pengemasan ikan pindang dan sosialisasi kepada masyarakat. Berdasarkan uji coba laboratorium, diketahui bahwa pengemasan vakum untuk produk ikan pindang bandeng dan mojang memberikan umur simpan 14 hari pada suhu ruang, dibanding ikan yang tidak dikemas (5 hari). Pada tahap sosialisasi dijelaskan cara pengemasan yang dilakukan, serta memperkenalkan Good Manufacturing Practices (GMP), selain menjaring aspirasi mengenai kebutuhan warga untuk pengembangan produksi ikan pindang.
\end{abstract}

Kata kunci: GMP; ikan pindang; pengemasan vakum

\begin{abstract}
People in Cukanggenteng Village, Ciwidey, Bandung, produce indigenous food product, which is cooked salted fish. Various salted cooked fish is available, such as milkfish, mojang fish, carp, etc. The products is sold from house to house and well sold. However this product has relatively short shelf life, thus limiting its marketing area. Salting is known as easy preservation method, but in this case, without proper food packaging, the fish shelf life is still not long enough for business expansion. This community service activity was the first year activity to do initial study about salted cooked fish preservation problem in Cukanggenteng Village. In this stage we did initial study of salted cooked fish production process, laboratory test to observe the shelf life of salted cooked fish with and without vaccuum packaging, and socialization of its result to fish producer in the village. Based on the test, we obtained that vaccuum packaged fish had 14 days shelf life, compared to ones not packaged. This result had been socialized to the fish producer, along with introduction of good manufacturing practices.
\end{abstract}

Keywords: good manufacturing practices, salted cooked fish, vacuum packaging

\section{PENDAHULUAN}

Masyarakat Desa Cukanggenteng, Ciwidey, Kabupaten Bandung memproduksi panganan khas berupa ikan pindang. Berbagai jenis ikan dapat diolah menjadi ikan pindang, di antaranya ikan mas, ikan bandeng, dan ikan mojang. Seorang perajin ikan pindang dapat mengolah dua puluh sampai seratus kilogram ikan mentah. Produk ikan pindang yang dibuat laku terjual, dengan sistem penjualan dijajakan dari rumah ke rumah, dari satu lokasi ke lokasi lain. Berdasarkan informasi dari para perajin, jika ikan pindang tidak habis dijual pada hari pertama, maka akan dijajakan kembali hari berikutnya. Pemindangan, proses memasak dengan menggunakan garam, memberikan cita rasa yang khas, selain meningkatkan umur simpan ikan (Margono, Suryati, \& Hartinah, 
2000). Peningkatan umur simpan dari ikan yang sudah dipindang diakibatkan oleh berkurangnya mikroorganisme selama pemasakan, serta penggunaan garam yang menurunkan nilai aktivitas air $\left(a_{w}\right)$ dari produk ikan yang mencegah pertumbuhan mikroorganisme (Pandit, 2013).

Oleh karena penyimpanan dan pengemasan ikan pindang yang sederhana, maka umur simpan dari ikan pindang menjadi relatif singkat, yaitu 3-5 hari, sehingga jumlah produksi dan area pemasaran menjadi terbatas. Salah satu solusi untuk meningkatkan umur simpan produk pangan yang paling sederhana adalah dengan menggunakan pengemasan vakum. Penambahan bahan pengawet seperti asam asetat, asam sitrat, asam sorbat, asam benzoat, natrium asetat, natrium benzoat, natrium propionat, dan sebagainya (Rahman, 2007) juga dapat dilakukan. Pengawetan dengan penambahan asam organik pernah diteliti oleh Wahyuningsih (2002), di mana penambahan kalium sorbat $(0,1 \%)$ dan natrium benzoat $(0,1 \%)$ dapat meningkatkan umur simpan ikan bandeng presto sampai 4 dan 5 hari (Wahyuningsih, 2002). Perendaman produk pindang ikan layang di dalam larutan kitosan $0,5 \%$ di dalam larutan asam asetat $0,08 \%$ dapat meningkatkan umur simpan produk mencapai 3 hari pada temperatur ruang (Ariyani \& Yennie, 2008). Kitosan berperan membentuk lapisan film di permukaan daging yang dapat melepas asam asetat secara bertahap, sehingga membantu proses pengawetan daging selama penyimpanan (Rahman, 2007). Akan tetapi, penggunaan pengawet makanan tidak dilakukan dalam kegiatan pengabdian ini, dikarenakan adanya penolakan dari masyarakat desa terhadap penggunaan bahan pengawet. Oleh karena itu, penggunaan metode pengemasan vakum menjadi alternatif yang digunakan dalam kegiatan ini.

Pengemasan vakum merupakan teknologi pewadahan makanan dalam kondisi hampa udara, sehingga kontak produk pangan dengan udara menjadi terbatas. Pengemasan vakum telah banyak digunakan sebelumnya untuk mengawetkan berbagai produk pangan, seperti ikan (Rodrigues et al., 2016; Zhang, Li, Li, Liu, \& Luo, 2015), udang (Young, Anang, \& Tiwari, 2014), ayam (Ntzimani, Giatrakou, \& Savvaidis, 2010), sosis (Cachaldora, García, Lorenzo, \& García-Fontán, 2013), dan lain-lain. Pengemasan vakum dipilih dengan pertimbangan bahwa teknologi pengemasan vakum relatif sederhana, tetapi efektif dalam meningkatkan umur simpan dari produk pangan, penambahan pengawet makanan sangat rentan terhadap kesalahan penambahan dosis sehingga beresiko, selain juga ada penolakan dan sugesti dari masyarakat di mana pengawet makanan dapat mengubah rasa/ kualitas dari produk. Kegiatan pengabdian ini dibagi menjadi dua tahap, yaitu uji coba di laboratorium untuk menentukan secara pasti umur simpan dari produk ikan pindang dengan dan tanpa pengemasan vakum, dan sosialisasi kepada perajin ikan pindang Desa Cukanggenteng. Pada tahap sosialisasi juga disampaikan mengenai cara produksi pangan yang baik (GMP).

\section{METODE}

\section{Sasaran Dan Waktu Kegiatan}

Kegiatan pengabdian masyarakat ini menyasar para perajin ikan pindang di Desa Cukanggenteng, Ciwidey, Kabupaten Bandung. Kegiatan ini dilakukan sejak Februari 2016 sampai Oktober 2016.

\section{Metode Kegiatan}

Metode kegiatan pengabdian ini adalah:

1. Studi awal kondisi produksi ikan pindang, di mana tim melihat langsung tahapan produksi yang dilakukan, selain mengamati berbagai penyimpangan yang perlu diperbaiki. Peran perajin dominan dalam kegiatan ini

2. Uji coba laboratorium untuk meyakinkan bahwa pengemasan vakum dapat meningkatkan keawetan produk ikan pindang. Peran tim dominan dalam kegiatan ini.

3. Sosialisasi hasil pengawetan, pembekalan proses penanganan produk pangan yang baik dan diskusi pengembangan produk ikan pindang ke depannya. Tim juga melakukan diskusi mengenai kesulitan yang dialami oleh para perajin ikan, terutama dari sisi bisnis, yang menyebabkan usaha para perajin menjadi kurang berkembang).

\section{Prosedur Uji Coba di Laboratorium}

Uji coba di laboritorium dilakukan dengan menyamakan perlakuan pada proses pemasakan ikan, sehingga dapat memberikan gambaran yang serupa dengan ikan yang diproduksi para perajin ikan. Proses pembuatan ikan pindang terdiri atas pembersihan ikan, pemberian bumbu (garam, vetsin, bawang putih, lengkuas, dan daun salam), kemudian ikan disusun dengan rapi di dalam panci bertekanan (panci presto) yang telah diisi air. Pemasakan dilakukan selama 3 jam, kemudian ikan dikeluarkan dari panci dan didinginkan, sebelum dikemas. Produk ikan kemudian dikemas dengan menggunakan kertas makanan, atau plastik vakum, dan disimpan pada suhu ruang. Perubahan visual dan jumlah koloni bakteri terhadap waktu menjadi parameter yang diamati. Pengamatan dilakukan pada hari ke- 1, 3, 5, 7, 8, dan 14 . Perhitungan jumlah koloni bakteri di dalam produk ikan pindang dilakukan dengan menggunakan analisa total plate count (TPC).

\section{HASIL DAN PEMBAHASAN \\ Studi Awal Produksi Ikan Pindang}

Studi awal metode produksi ikan pindang yang dilakukan oleh tim pada awal periode kegiatan. Metode produksi ikan pindang yang diperoleh disajikan pada sub bab 2.3. Beberapa temuan lain yang perlu diperbaiki dan menjadi bahan sosialiasi pada akhir kegiatan, disajikan pada sub bab 3.3.

\section{Uji Coba Laboratorium Pengawetan Dengan Kemasan Vakum}

Hasil observasi visual produk ikan pindang yang dikemas dengan menggunakan kertas makanan dan 
kemasan vakum disajikan pada Gambar 1. Berdasarkan pengamatan visual, dapat dilihat bahwa produk ikan yang disimpan sampai hari ke-3 masih dalam kondisi baik, yaitu tidak berbau, tidak berlendir, dan tidak nampak jamur pada permukaan ikan. Sementara itu pada hari ke-7 nampak produk ikan menjadi lebih lunak diduga dikarenakan adanya peningkatan kadar air pada produk ikan. Sementara itu, produk ikan yang dikemas dengan kemasan kertas menunjukkan adanya jamur di permukaan ikan pada hari ke-8 dan ke-14 (ditandai dengan lingkaran pada Gambar 1), selain bau ikan menjadi busuk dan permukaan ikan berlendir. Sementara pada sampel ikan yang dikemas secara vakum tidak menunjukkan tanda-tanda kerusakan di atas.

Pada hasil analisa TPC (Gambar 2), dapat diamati terjadi kenaikan jumlah koloni seiring penyimpanan produk ikan. Berdasarkan nilai TPC, produk ikan pindang bandeng dan mojang yang dikemas dengan kertas masih dapat dikonsumsi dengan nilai TPC $5,2 \times 10^{4}$ dan $6,8 \times 10^{4}$. Sementara setelah hari ke-8, nilai TPC melewati ambang batas yang ditetapkan dalam Keppres No. 20 tahun 1984 dan Keppres No. 7 tahun1989, yaitu sebesar $1 \times 10^{5}$. Pada produk ikan pindang bandeng dan mojang yang dikemas secara vakum memiliki nilai TPC $8 \times 10^{4}$ dan $1 \times 10^{5}$ pada hari ke-14. Berdasarkan pengamatan visual dan jumlah koloni bakteri, maka dapat disimpulkan umur simpan ikan pindang bandeng dan mojang dengan kertas makanan sampai 5 hari, dan untuk ikan pindang yang dikemas secara vakum sampai 14 hari pada suhu ruang. Peningkatan umur simpan ini dimungkinkan karena sifat dari kemasan vakum yang melindungi produk di dalamnya dari lingkungan, serta membatasi kontak produk dengan udara, air, aroma, dan matahari yang dapat merubah kualitas produk (Rahman, 2007). Selain itu kondisi penyimpanan yang hampa udara menghambat perkembangbiakan bakteri aerobik, dan hanya beberapa bakteri seperti $S$. putrefaciens, bakteri vegetatif, clostridia, dan Bacillus yang bertahan sebagai spora (Gram et al., 2002). Hal ini nampak dalam peningkatan koloni bakteri yang relatif landai dibanding produk ikan yang dikemas dengan kertas makanan.
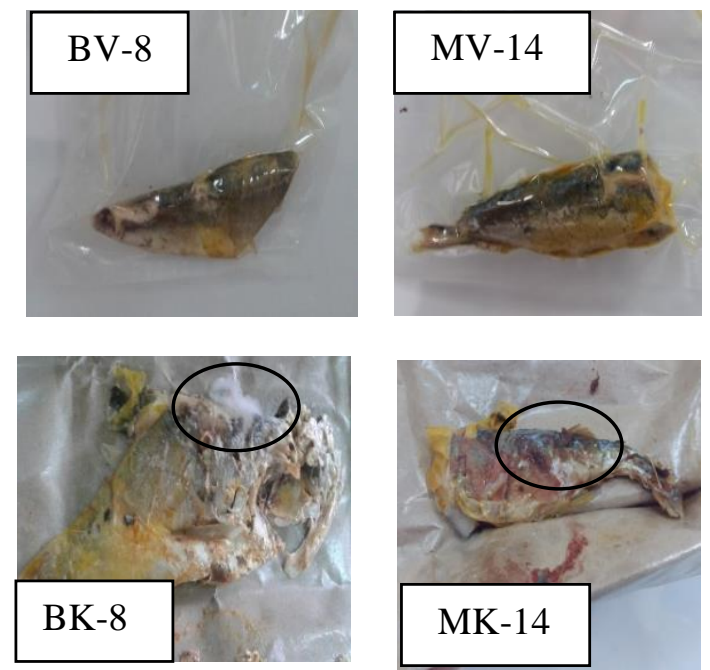

Gambar 1. Produk ikan pindang bandeng (B) dan mojang $(\mathrm{M})$ dengan kemasan vakum $(\mathrm{V}-\mathrm{x})$ dan kertas $(\mathrm{K}-\mathrm{x})$, pada hari penyimpanan $(\mathrm{x})$

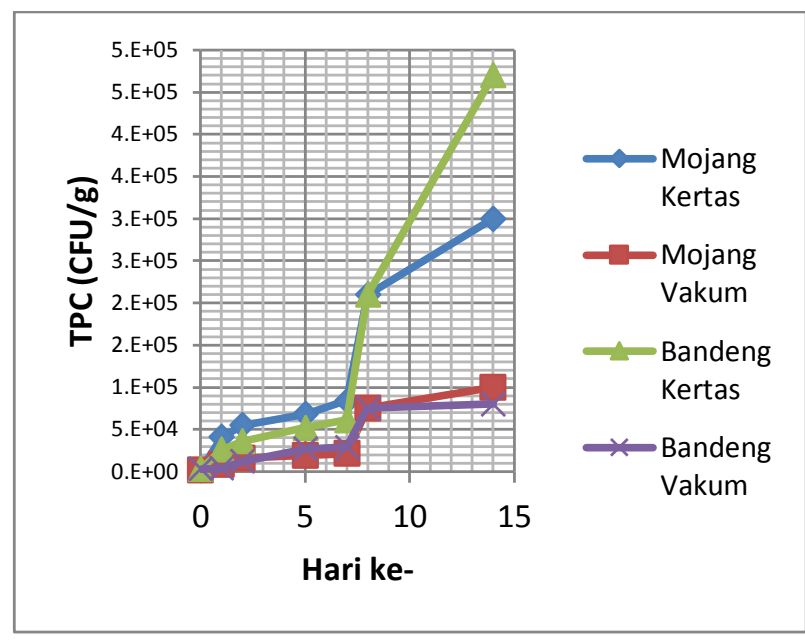

Gambar 2. Hasil analisa TPC terhadap hari penyimpanan

\section{Sosialisasi Pengawetan Vakum}

Kegiatan sosialisasi (Gambar 3) kepada para perajin ikan di Desa Cukanggenteng bertujuan untuk membuka wawasan warga terhadap potensi pemasaran produk ikan yang telah dikemasa vakum, selain menggali lebih lanjut kebutuhan warga akan pemasaran produk ikan pindang. Terlihat antusiasme warga dalam kegiatan sosialisasi awal ini, di mana banyak perajin ikan pindang yang hadir. Para perajin ikan juga diberikan penyuluhan mengenai produksi pangan yang baik, di antaranya pentingnya menjaga kebersihan diri dan higienitas selama proses produksi, selain juga menjaga kualitas bahan baku. Terdapat pula perajin ikan yang tertarik untuk mencoba pengemasan vakum, dan menjadi percontohan.

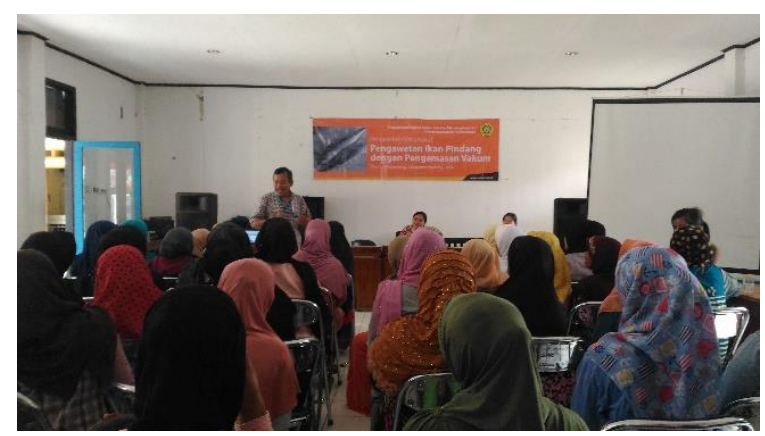

Gambar 3. Antusiasme para perajin ikan mengikuti sosialisasi

Hasil temuan selama kegiatan ini lebih lanjut dijabarkan sebagai berikut:

\section{Proses Produksi}

Selain terdapat kekurangan pada proses penyimpanan dan pengemasan ikan, ditemukan pula bahwa perajin ikan belum menerapkan cara produksi pangan yang baik (good manufacturing practices), padahal hal ini sangat penting untuk menjamin kualitas dan keamanan 
produk pangan (food safety) (Raspor, 2008). GMP merupakan suatu pedoman yang digunakan untuk memastikan bahwa produk pangan yang dihasilkan bermutu dan aman dikonsumsi (BPOM, 2012). Dalam peraturan yang dikeluarkan oleh BPOM pada tahun 2012 mengenai cara produksi pangan yang baik untuk industri rumah tangga (CPPB-IRT), dijelaskan berbagai aspek yang perlu diperhatikan dalam produksi pangan antara lain, lokasi dan lingkungan produksi, bangunan dan fasilitas produksi, peralatan yang digunakan, suplai air, fasilitas sanitasi dan higienitas, kesehatan dan hygiene karyawan, penyimpanan bahan baku, alat produksi, dan produk akhir, serta pengemasan pangan. Penerapan GMP secara umum bertujuan untuk meminimalkan kontaminasi baik secara fisika, kimia, atau pun biologis yang berasal dari berbagai hal (antara lain lingkungan, bahan baku, pekerja) terhadap produk pangan, sehingga keamanan pangan dapat terjamin. Lebih lanjut, GMP merupakan bagian dari manajemen kualitas keamanan pangan (Raspor, 2008).

Merujuk pada berbagai aspek GMP di atas, beberapa hal yang perlu diperhatikan dalam produksi ikan pindang di Desa Cukanggenteng antara lain, bahan baku yang kurang baik, proses pemasakan kurang higienis, selain lingkungan produksi yang kurang baik. Bahan baku ikan yang digunakan terkadang kurang segar, selain bumbu-bumbu yang digunakan juga seringkali tidak lengkap. Hal ini dikarenakan bahan baku produksi yang digunakan berasal dari pasar induk di Kota Bandung, sehingga pembelian menjadi tidak rutin melalui pemasok ikan, selain perajin juga tidak dapat memilih sendiri bahan baku yang digunakan.
Pada proses pemasakan, bagian perut ikan akan dibungkus dengan kertas khusus, untuk mencegah bentuk ikan rusak (hancur) selama pemasakan. Pada beberapa perajin ditemukan kertas pembungkus ini digunakan kertas Koran. Padahal diketahui bahwa kertas koran mengandung logam berat yang dapat mencemari makanan (Agustina, 2014). Selain itu, teramati pula bahwa baik bahan baku atau pun produk ikan pindang jadi diletakkan di nampan yang ditaruh di atas lantai, selain cukup banyak hewan peliharaan warga yang berkeliaran sehingga produksi menjadi kurang higienis.

\section{Pengelolaan Bisnis}

Terdapat keluhan dari perajin di mana ada keterbatasan modal, akan tetapi hal ini diiringi keengganan perajin ikan untuk meminjam uang dari bank. Selain itu para perajin ikan tidak memiliki sistem pencatatan keuangan, padahal pencatatan keuangan sangat penting bagi seorang pengusaha untuk mengetahui perkembangan usahanya (Narsa, Widodo, \& Kurnianto, 2012), selain juga menjadi bahan pertimbangan saat akan mengajukan pinjaman keuangan pada pihak bank.

Berbagai temuan di atas serta solusi yang disarankan kepada para perajin ikan dan pemerintah Desa Cukanggenteng disajikan pada Tabel 1. Berdasarkan temuan dalam interaksi dengan para perajin ikan, dilakukan analisa dan rencana pengembangan yang dapat dilakukan yang kan menjadi kegiatan pada tahun kedua. Rencana pengembangan tersebut disajikan dalam Gambar 4.

Tabel 1. Temuan dan tindakan yang disarankan kepada pejabat pemerintah Desa dan perajin ikan

\begin{tabular}{|c|c|}
\hline Temuan & Tindakan yang disarankan \\
\hline $\begin{array}{l}\text { Keterbatasan modal, perajin ikan perlu berhutang } \\
\text { kepada pemasok ikan jika memulai usaha atau } \\
\text { menambah kapasitas produksi }\end{array}$ & Perlu peminjaman modal dari bank atau koperasi \\
\hline Tidak memiliki catatan keuangan & Pelatihan pencatatan keuangan \\
\hline $\begin{array}{l}\text { Perajin ikan berusaha sendiri-sendiri dalam pembelian } \\
\text { bahan atau pun penjualan produk }\end{array}$ & $\begin{array}{l}\text { Perlu dibentuk badan koperasi perajin ikan, sehingga } \\
\text { pembelian bahan dapat dalam partai besar }\end{array}$ \\
\hline $\begin{array}{l}\text { Bahan baku ikan kadang-kadang kurang segar, bumbu- } \\
\text { bumbu seringkali tidak lengkap }\end{array}$ & $\begin{array}{l}\text { Ikan langsung diolah setelah dibeli, keberadaan } \\
\text { koperasi sangat membantu }\end{array}$ \\
\hline $\begin{array}{l}\text { Penggunaan kertas koran sebagai pembungkus perut } \\
\text { ikan saat memasak }\end{array}$ & $\begin{array}{l}\text { Menggunakan kertas ikan yang aman untuk produk } \\
\text { pangan }\end{array}$ \\
\hline $\begin{array}{l}\text { Produk ikan yang sudah jadi didinginkan di atas } \\
\text { nampan, tetapi ditaruh di atas lantai }\end{array}$ & $\begin{array}{l}\text { Penyuluhan: produk pangan tidak boleh ditaruh di atas } \\
\text { lantai }\end{array}$ \\
\hline Banyak hewan berkeliaran di area memasak & Penyuluhan: area memasak perlu steril dari hewan \\
\hline
\end{tabular}




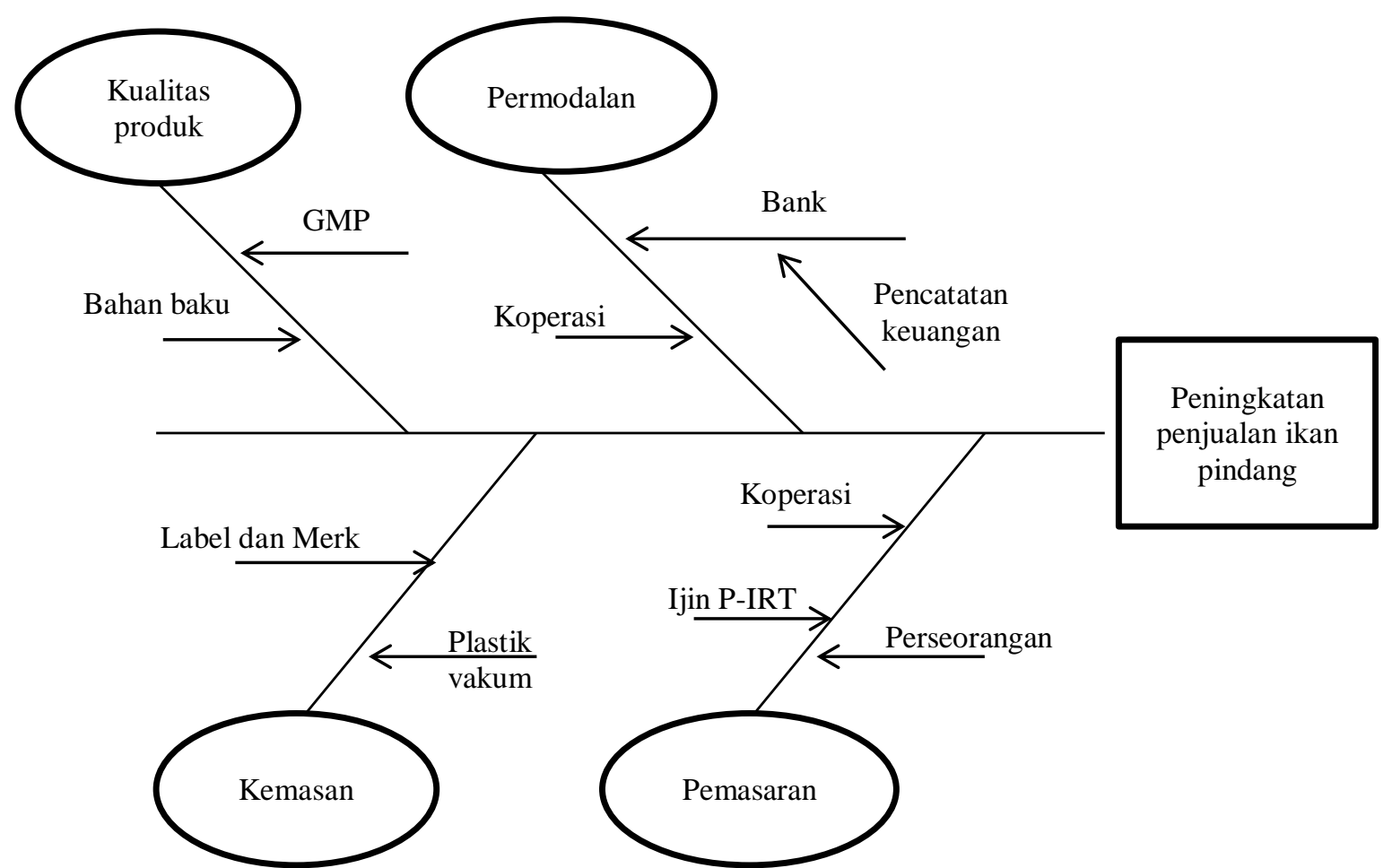

Gambar 4. Fishbone diagram untuk menganalisa dan merencanakan kebutuhan perajin ikan Desa Cukanggenteng

\section{KESIMPULAN}

Berdasarkan kegiatan yang telah dilakukan, dapat disimpulkan bahwa pengemasan vakum telah berhasil meningkatkan umur simpan ikan pindang bandeng dan mojang sampai 14 hari pada suhu ruang. Sosialisasi mengenai pengemasan vakum dan GMP telah diberikan, akan tetapi perlu percontohan dan pendampingan lebih lanjut yang akan dilakukan pada tahun kedua kegiatan, sehingga ke depannya produk ikan pindang yang dihasilkan dapat diproduksi dan dijual dalam jumlah besar, dan pada akhirnya meningkatkan kesejahteraan para perajin ikan di Desa Cukanggenteng.

\section{UCAPAN TERIMA KASIH}

Kegiatan pengabdian masyarakat ini dibiayai oleh Lembaga Penelitian dan Pengabdian Masyarakat (LPPM) UNPAR melalui Hibah Internal Program Pengabdian Kepada Masyarakat dengan kontrak No III/LPPM/2016-02/17-PM. Tim mengucapkan terima kasih atas pembiayaan yang diberikan.

\section{DAFTAR PUSTAKA}

Agustina, T. (2014). Kontaminasi Logam Berat Pada Makanan Dan Dampaknya Pada Kesehatan. TEKNOBUGA, 1(1), 53-65.

Ariyani, F., \& Yennie, Y. (2008). Pengawetan Pindang Ikan Layang (Decapterus russelli) menggunakan kitosan. Jurnal Pascapanen dan Bioteknologi Kelautan dan Perikanan, 3(2), 139-146.
BPOM. (2012). Peraturan Kepala Badan Pengawas Obat dan Makanan Republik Indonesia No HK. 03.1.23.04.12.2206 tentang Produksi Pangan yang Baik Untuk Industri Rumah Tangga. Jakarta

Cachaldora, A., García, G., Lorenzo, J. M., \& GarcíaFontán, M. C. (2013). Effect of modified atmosphere and vacuum packaging on some quality characteristics and the shelf-life of "morcilla", a typical cooked blood sausage. Meat Science, 93, 220-225.

Gram, L., Ravn, L., Rasch, M., Bruhn, J. B., Christensen, A. B., \& Givskov, M. (2002). Food spoilage-interactions between food spoilage bacteria. International Journal of Food Microbiology, 78, 79- 97.

Margono, T., Suryati, D., \& Hartinah, S. (2000). Ikan Pindang Air Garam. In Kantor Deputi Menergistek Bidang Pendayagunaan dan Pemasyarakatan Ilmu Pengetahuan dan Teknologi, (pp. 1-5). Jakarta.

Narsa, I. M., Widodo, A., \& Kurnianto, S. (2012). Mengungkap Kesiapan Umkm Dalam Implementasi Standar Akuntansi Keuangan Entitas Tanpa Akuntabilitas Publik (PSAKETAP) Untuk Meningkatkan Akses Modal Perbankan. Majalah Ekonomi, 22(3), 204-214.

Ntzimani, A. G., Giatrakou, V. I., \& Savvaidis, I. N. (2010). Combined natural antimicrobial treatments (EDTA, lysozyme, rosemary and oregano oil) on semi cooked coated chicken 
meat stored in vacuum packages at $4{ }^{\circ} \mathrm{C}$ : Microbiological and sensory evaluation. Innovative Food Science and Emerging Technologies, 11, 187-196.

Pandit, I. G. S. (2013). Perbaikan Cara Pengolahan Ikan Pindang. Jurusan Perikanan, Fakultas Pertanian, Universitas Warmadewa.

Rahman, M. S. (2007). Handbook of Food Preservation 2nd edition. Boca Raton: CRC Press.

Raspor, P. (2008). Total food chain safety: How good practices can contribute?. Trends in Food Science \& Technology, 19(8), 405-412.

Rodrigues, B. L., Alvares, T. d. S., Sampaio, G. S. L., Cabral, C. C., Araujo, J. V. A., Franco, R. M., Junior, C. A. C. (2016). Influence of vacuum and modified atmosphere packaging in combination with UV-C radiation on the shelf life of rainbow trout (Oncorhynchus mykiss) fillets. Food Control, 60, 596-605.

Wahyuningsih, S. (2002). Penggunaan Natrium Benzoat dan Kalium Sorbat Pada Pengawetan Ikan Bandeng (Chanos chanos) Presto. Skripsi Sarjana. Institut Pertanian Bogor.

Young, H., Anang, D. M., \& Tiwari, B. K. (2014). Shelf life and textural properties of cooked-chilled black tiger prawns (Penaeus monodon) stored in vacuum pack or modified atmospheric packaging at 4 or $20^{\circ} \mathrm{C}$. Food Packaging and Shelf Life, 2, 59-64.

Zhang, Y., Li, Q., Li, D., Liu, X., \& Luo, Y. (2015) Changes in the microbial communities of airpackaged and vacuum packaged common carp (Cyprinus carpio) stored at $4^{\circ} \mathrm{C}$. Food Microbiology, 52, 197-204. 